\title{
Seasonal variations in chromium concentration in urban atmospheric aerosol in the city of Radom
}

\author{
Artur Molik ${ }^{1}$, Marzena Trojanowska ${ }^{1}$, Monika Łożyńska² and Ryszard Świetlik ${ }^{1}$
}

${ }^{1}$ Kazimierz Pulaski University of Technology and Humanities, Department of Environmental Protection, 26-600 Radom, B. Chrobrego 27, Poland

${ }^{2}$ Warsaw University of Technology, Faculty of Building Services, Hydro and Environmental Engineering, 00-653 Warsaw, Nowowiejska 20, Poland

\begin{abstract}
This paper presents seasonal variations in the occurrence of chromium in urban particulate matter (PM). Radom is an interesting area for this type of research due to its typical antiquated heating infrastructure. PM samples of two particulate fractions PM2.5 (particulates $\leq 2.5 \mu \mathrm{m}$ ) and PM10 (particulates $\leq 10 \mu \mathrm{m}$ ) were collected using a Copley cascade impactor Hi-Flow MOUDI Model 130. Chromium was determined in the samples using the GF-AAS technique. The concentration of chromium in PM2.5 was in the range of 0.38 to $3.2 \mathrm{ng} / \mathrm{m}^{3}$, whereas in PM10 it ranged from 0.43 to $4.1 \mathrm{ng} / \mathrm{m}^{3}$.
\end{abstract}

\section{Introduction}

Atmospheric particulates are a dominant form of urban air pollution. They originate from both natural and anthropogenic sources. It is assumed that the coarse fraction $(2.5-10$ $\mu \mathrm{m})$ is of natural origin whereas anthropogenic processes are the source of the fine fraction $(\leq 2.5 \mu \mathrm{m})$. The distribution of particle sizes and chemical compositions determine the impact of the atmospheric aerosol on the environment. The composition of particulate matter is complex and heterogeneous $[1,2]$. Particulate matter with particle diameters of below $2.5 \mu \mathrm{m}$ is very dangerous for living organisms. It penetrates deep into the alveoli from where it can enter the circulatory system [2, 3]. Various toxic compounds are transported with the particles. Heavy metals are the group of pollutants to which particular attention is paid [2-4].

Heavy metals can be found primarily in the fine fraction [3-5]. They are generally regarded as toxic for living organisms. Several of them, e.g. $\mathrm{Cr}, \mathrm{Cd}$ and $\mathrm{Ni}$, are carcinogenic. Therefore, they are permanently monitored in the environment $[3,4]$. The characteristic feature of heavy metals is their stability - they do not undergo biodegradation. They usually remain in the environment in the form in which they were emitted. Their bioaccumulation increases their danger to living organisms $[6,7]$.

\footnotetext{
* Corresponding author: artur.molik@,uthrad.pl
} 
Chromium is one of the heavy metals whose presence in excessive amounts is a threat to the biotic component of the environment. Anthropogenic sources are responsible for $60 \%$ to $70 \%$ of chromium emission to the atmosphere while natural sources emit $30 \%$ to $40 \%$ [8]. With a share of about $42 \%$, non-industrial combustion processes play a dominant role in the chromium emission in Poland. Combustion processes in industry, manufacturing processes and combustion processes in the energy production and transformation, 19\%, $17 \%$ and $13 \%$ respectively, are considerably less important. The share of road transport has been increasing steadily in recent years with about $9 \%$ in 2015 [9].

There are many publications on the occurrence and speciation of heavy metals, including chromium [2-7]. There has been an increasing interest in seasonal variations in the concentration of heavy metals in atmospheric aerosol and its probable effect on the estimation of inhalation hazard for city dwellers [11-18, 21, 24]. There is little interest in chromium in this respect, particularly in domestic literature [19-20, 22-23].

This work presents the results of the study of seasonal fluctuations in the occurrence of chromium in urban atmospheric aerosol in the city of Radom. The aim of the study was to diagnose main chromium emission sources and to create a basis for prediction of air pollution in Radom.

\section{Materials and methods}

\subsection{Study area and sampling collection}

Radom is a medium-sized city (pop. 217,000) located in the southern part of the Mazowsze province. It covers an area of $111.8 \mathrm{~km}^{2}$. The city is an interesting site for this type of study due to its outdated heating system which is typical of Poland.

The aerosol sampling site was located on the grounds of the Faculty of Materials Science and Design of the University of Technology and Humanities in Radom (Fig. 1). Aerosol samples were collected in four successive seasons $(2015 / 2016)$ using a Hi-Flow MOUDI Model 130 cascade impactor (Copley Scientific). Using the device it is possible to separate particle fractions PM10 and PM2.5.

The particulates were deposited on cellulose filters produced by POCh. Before and after collection of aerosol samples the filters were weighed three times using a Mettler Toledo MX5 microbalance and a mean mass of the filter was determined on this basis. The rate of air flow through the impactor was $100 \pm 2.5 \mathrm{~L} / \mathrm{min}$. Each sample was collected during seven days, the sampler operated for 12 hours per day - each working hour was followed by a one-hour break for cooling of the pump which sucked in the air.

\subsection{Analytical procedures}

A Milestone MLS 1200 Mega microwave digestion unit was used to extract chromium from the collected samples of atmospheric particulates. One fourth of the filter was placed in a Teflon vessel containing $5 \mathrm{~mL} 65 \% \mathrm{HNO}_{3}$ and $1 \mathrm{~mL} 30 \% \mathrm{H}_{2} \mathrm{O}_{2}$. The samples were digested under standard conditions. After digestion the solutions were filtered into $25 \mathrm{~mL}$ volumetric flasks which were then made up to the mark with deionized water. 


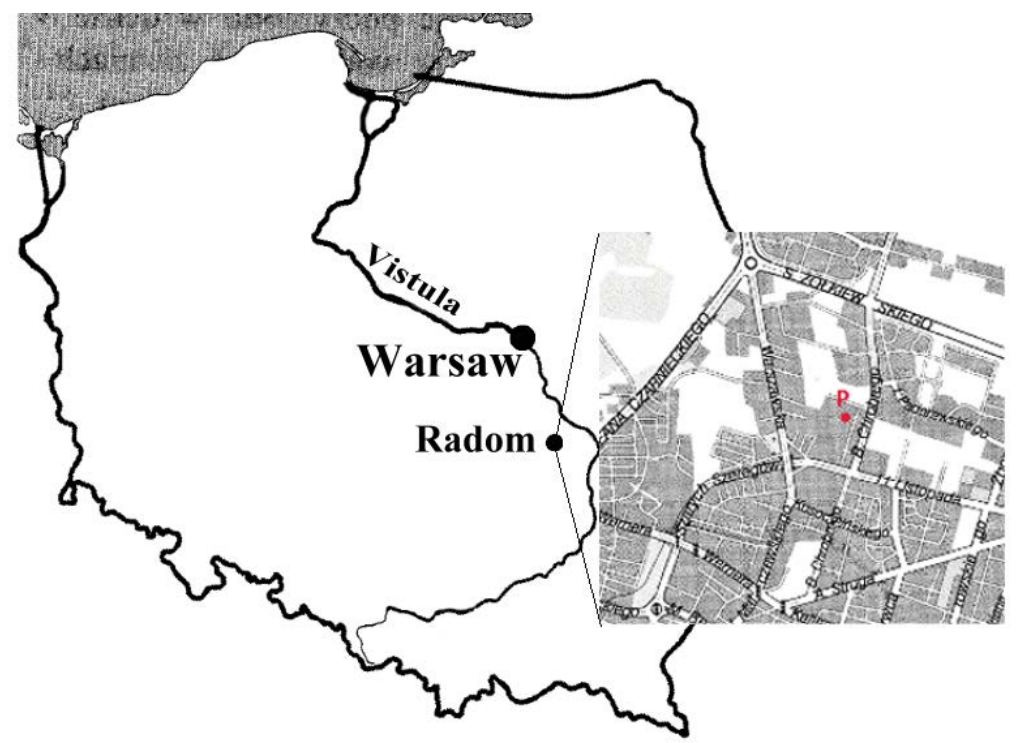

Fig. 1. The location of the sampling site in the Radom city.

The determination of the chromium concentration in the digests from individual particle fractions of the particulates was carried out by means of a Perkin-Elmer AAS 3100 spectrometer equipped with a graphite furnace HGF 600. Standard solution of chromium (J. T. Baker Inc.) with concentration of $1000 \mu \mathrm{g} / \mathrm{mL}$ was used to calibrate the device. LOD (instrumental) was found to be $0.2 \mu \mathrm{g} / \mathrm{L}$ of $\mathrm{Cr}$ or $0.3 \mathrm{ng} / \mathrm{m}^{3}$ as the concentration of $\mathrm{Cr}$ in air.

\section{Results and discussion}

The concentrations of PM10, PM2.5 and chromium are given in Table 1.

Table 1. Concentrations of PM10, PM2.5 and chromium.

\begin{tabular}{|c|c|c|c|c|c|}
\hline \multirow[b]{2}{*}{$\begin{array}{l}\text { Sample } \\
\text { number }\end{array}$} & \multirow{2}{*}{$\begin{array}{c}\text { Sampling } \\
\text { time }\end{array}$} & \multicolumn{2}{|c|}{ PM10 } & \multicolumn{2}{|c|}{ PM2.5 } \\
\hline & & $\begin{array}{c}\text { PM } \\
{\left[\mu \mathrm{g} / \mathbf{m}^{3}\right]}\end{array}$ & $\begin{array}{c}\mathrm{Cr} \\
{\left[\mathrm{ng} / \mathrm{m}^{3}\right]}\end{array}$ & $\begin{array}{c}\mathbf{P M} \\
{\left[\mu \mathrm{g} / \mathrm{m}^{3}\right]}\end{array}$ & $\begin{array}{c}\mathrm{Cr} \\
{\left[\mathrm{ng} / \mathrm{m}^{3}\right]}\end{array}$ \\
\hline P.1 & \multirow{3}{*}{ Spring } & 18 & 1.1 & 14 & 1.0 \\
\hline P.2 & & 21 & 1.5 & 17 & 1.4 \\
\hline P.3 & & 9.7 & 0.78 & 6.3 & 0.66 \\
\hline P.4 & \multirow{6}{*}{ Summer } & 32 & 0.82 & 25 & 0.64 \\
\hline P.5 & & 27 & 2.3 & 22 & 2.2 \\
\hline P.6 & & 24 & 1.3 & 17 & 1.1 \\
\hline P.7 & & 43 & 2.2 & 33 & 1.8 \\
\hline P.8 & & 23 & 1.8 & 19 & 1.4 \\
\hline P.9 & & 22 & 1.1 & 17 & 0.75 \\
\hline
\end{tabular}

Table 1. Concentrations of PM10, PM2.5 and chromium (continued).

\begin{tabular}{|c|c|c|c|}
\hline Sample & Sampling & PM10 & PM2.5 \\
\hline
\end{tabular}




\begin{tabular}{|c|c|c|c|c|c|}
\hline number & time & $\begin{array}{c}\mathbf{P M} \\
{\left[\mu \mathrm{g} / \mathrm{m}^{3}\right]}\end{array}$ & $\begin{array}{c}\mathrm{Cr} \\
{\left[\mathrm{ng} / \mathrm{m}^{3}\right]}\end{array}$ & $\begin{array}{c}\mathbf{P M} \\
{\left[\mu \mathrm{g} / \mathrm{m}^{3}\right]}\end{array}$ & $\begin{array}{c}\mathrm{Cr} \\
{\left[\mathrm{ng} / \mathrm{m}^{3}\right]}\end{array}$ \\
\hline P.10 & \multirow{9}{*}{ Autumn } & 31 & 0.88 & 24 & 0.65 \\
\hline P.11 & & 50 & 4.1 & 38 & 3.2 \\
\hline P.12 & & 51 & 1.7 & 41 & 1.2 \\
\hline P.13 & & 57 & 0.75 & 47 & 0.72 \\
\hline P.14 & & 68 & 0.56 & 59 & 0.41 \\
\hline P.15 & & 49 & 0.43 & 40 & 0.38 \\
\hline P.16 & & 54 & 1.5 & 47 & 0.88 \\
\hline P.17 & & 61 & 1.5 & 54 & 1.3 \\
\hline P.18 & & 59 & 1.2 & 49 & 0.92 \\
\hline P.19 & \multirow{7}{*}{ Winter } & 56 & 2.4 & 52 & 2.0 \\
\hline P.20 & & 46 & 1.6 & 42 & 1.4 \\
\hline P.21 & & 41 & 1.7 & 34 & 1.4 \\
\hline P. 22 & & 39 & 2.3 & 32 & 1.7 \\
\hline P.23 & & 60 & 2.0 & 50 & 1.5 \\
\hline P.24 & & 61 & 2.2 & 52 & 1.6 \\
\hline P. 25 & & 34 & 2.3 & 30 & 2.1 \\
\hline
\end{tabular}

The concentration of PM10 ranged from 9.7 to $68 \mu \mathrm{g} / \mathrm{m}^{3}$. Its highest value was observed in autumn whereas the lowest one was found in spring. Distinct seasonal variations can be observed in the occurrence of PM10. Mean concentrations of this fraction decreased in the order: autumn $\left(53.3 \mu \mathrm{g} / \mathrm{m}^{3}\right)>$ winter $\left(48.1 \mu \mathrm{g} / \mathrm{m}^{3}\right)>\operatorname{summer}\left(28.5 \mu \mathrm{g} / \mathrm{m}^{3}\right)>$ spring $(16.2$ $\mu \mathrm{g} / \mathrm{m}^{3}$ ) (Fig. 2). The concentration of PM2.5 ranged from 6.3 to $59 \mu \mathrm{g} / \mathrm{m}^{3}$. The highest concentration of this fraction was found in autumn and the lowest one was observed in spring. The concentrations of PM2.5 also underwent seasonal changes. Its mean concentrations decreased in the order: autumn $\left(44.3 \mu \mathrm{g} / \mathrm{m}^{3}\right)>$ winter $\left(41.7 \mu \mathrm{g} / \mathrm{m}^{3}\right)>$ summer $\left(22.2 \mu \mathrm{g} / \mathrm{m}^{3}\right)>$ spring $\left(12.4 \mu \mathrm{g} / \mathrm{m}^{3}\right)$. PM2.5 concentrations were lower than the corresponding PM10 concentrations but the differences were not statistically valid.

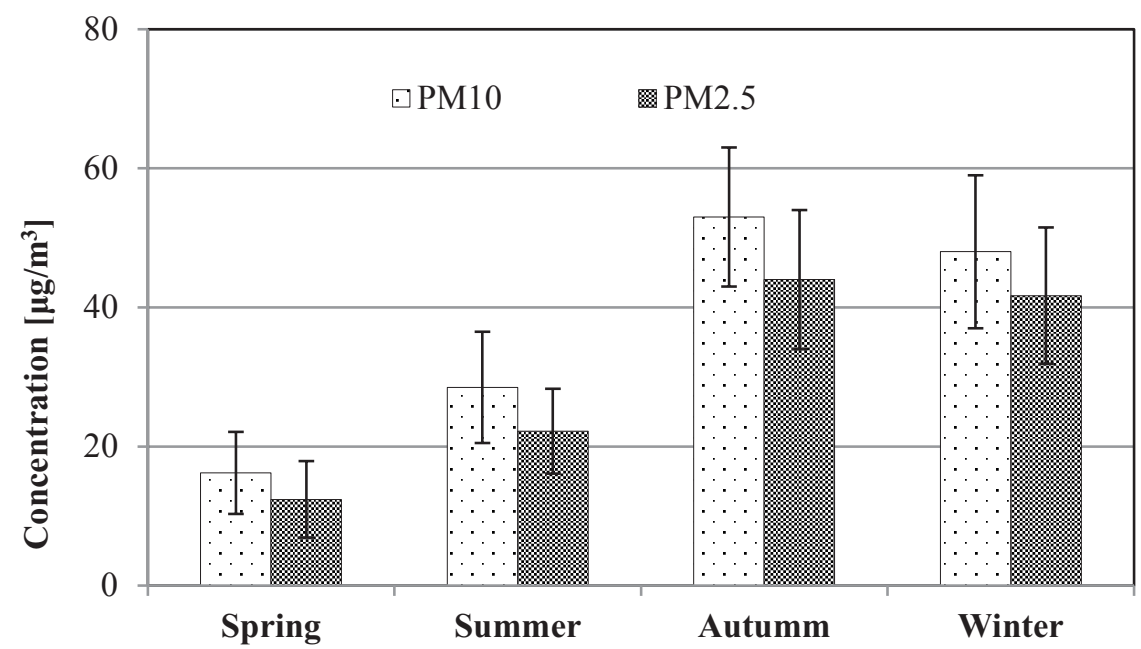

Fig. 2. Concentrations of PM2.5 and PM10 in urban air in Radom. 
Seasonality also had an effect on the content of PM2.5 in PM10. In the spring-summer period the ratio of PM2.5/PM10 was $76 \%$ and $78 \%$, respectively. In the autumn-winter period the ratio was higher: $83 \%$ and $87 \%$, respectively.

The determined PM10 and PM2.5 concentrations are typical of urban areas in various parts of the world [19-24]. Table 2 shows a comparison of the mean values obtained in this study with the data from other publications.

Table 2. Comparison of mean concentrations of PM10, PM2.5 and $\mathrm{Cr}$ in various cities in the world.

\begin{tabular}{|c|c|c|c|c|c|c|}
\hline \multirow[b]{2}{*}{$\begin{array}{c}\text { City } \\
\text { (Country) }\end{array}$} & \multirow{2}{*}{$\begin{array}{l}\text { Sampling } \\
\text { time }\end{array}$} & \multicolumn{2}{|c|}{ PM10 } & \multicolumn{2}{|c|}{ PM2.5 } & \multirow[b]{2}{*}{ References } \\
\hline & & $\begin{array}{c}\mathbf{P M} \\
{\left[\mu \mathrm{g} / \mathrm{m}^{3}\right]}\end{array}$ & $\begin{array}{c}\mathrm{Cr} \\
{\left[\mathrm{ng} / \mathrm{m}^{3}\right]}\end{array}$ & $\begin{array}{c}\mathbf{P M} \\
{\left[\mu \mathrm{g} / \mathrm{m}^{3}\right]}\end{array}$ & $\begin{array}{c}\mathrm{Cr} \\
{\left[\mathrm{ng} / \mathrm{m}^{3}\right]}\end{array}$ & \\
\hline \multirow{4}{*}{$\begin{array}{l}\text { Radom } \\
\text { (Poland) }\end{array}$} & Spring & 16.2 & 1.13 & 12.4 & 1.02 & \multirow{4}{*}{ This study } \\
\hline & Summer & 28.5 & 1.59 & 22.2 & 1.32 & \\
\hline & Autumn & 53.3 & 1.40 & 44.3 & 1.07 & \\
\hline & Winter & 48.1 & 2.07 & 41.7 & 1.67 & \\
\hline $\begin{array}{c}\text { Zabrze } \\
\text { (Poland) }\end{array}$ & Winter & 42 & 4.98 & - & - & [19] \\
\hline \multirow{2}{*}{$\begin{array}{l}\text { Kraków } \\
\text { (Poland) }\end{array}$} & Winter & - & - & 50 & 7.1 & \multirow{2}{*}{ [20] } \\
\hline & Summer & - & - & 16 & $<$ LOD & \\
\hline $\begin{array}{l}\text { Kraków } \\
\text { (Poland) }\end{array}$ & & - & - & 22 & 2.5 & [22] \\
\hline $\begin{array}{c}\text { Zabrze } \\
\text { (Poland) }\end{array}$ & Winter & - & - & 228 & $12-54$ & [23] \\
\hline $\begin{array}{c}\text { Vienna } \\
\text { (Austria) }\end{array}$ & & 30.4 & 0.8 & 21.5 & 0.4 & [24] \\
\hline $\begin{array}{c}\text { Oporto } \\
\text { (Portugal) }\end{array}$ & & 53.2 & 6.08 & 38.8 & 3.05 & [21] \\
\hline \multirow{2}{*}{$\begin{array}{l}\text { Lecce } \\
\text { (Italy) }\end{array}$} & $\begin{array}{l}\text { Warm } \\
\text { season }\end{array}$ & 24.8 & - & 15.2 & - & \multirow{2}{*}{ [12] } \\
\hline & $\begin{array}{c}\text { Cold } \\
\text { season }\end{array}$ & 34.7 & - & 22.5 & - & \\
\hline \multirow{4}{*}{$\begin{array}{l}\text { Wuhan } \\
\text { (China) }\end{array}$} & Winter & - & - & 142.9 & 8.97 & \multirow{4}{*}{ [11] } \\
\hline & Spring & - & - & 132.7 & 9.04 & \\
\hline & Autumn & - & - & 101.8 & 8.20 & \\
\hline & Summer & - & - & 48.6 & 5.41 & \\
\hline $\begin{array}{c}\text { Changsha } \\
\text { (China) }\end{array}$ & Winter & 170 & 26.5 & - & - & [15] \\
\hline \multirow{3}{*}{$\begin{array}{l}\text { Hong Kong } \\
\text { (China) }\end{array}$} & Winter & - & - & - & 4.1 & \multirow{3}{*}{ [18] } \\
\hline & Summer & - & - & - & 6.8 & \\
\hline & Summer & & & 16 & $<$ LOD & \\
\hline
\end{tabular}

The concentration of chromium in PM10 ranged from 0.43 to $4.1 \mathrm{ng} / \mathrm{m}^{3}$ (Table 1). Its highest value was found in winter while its lowest value was observed in spring. Seasonal changes can also be observed in the occurrence of chromium in this fraction. Its average concentrations decreased in the order: winter $-2.07 \mathrm{ng} / \mathrm{m}^{3}$, summer $-1.59 \mathrm{ng} / \mathrm{m}^{3}$, autumn $1.40 \mathrm{ng} / \mathrm{m}^{3}$ and spring $-1.13 \mathrm{ng} / \mathrm{m}^{3}$ (Fig. 3). 


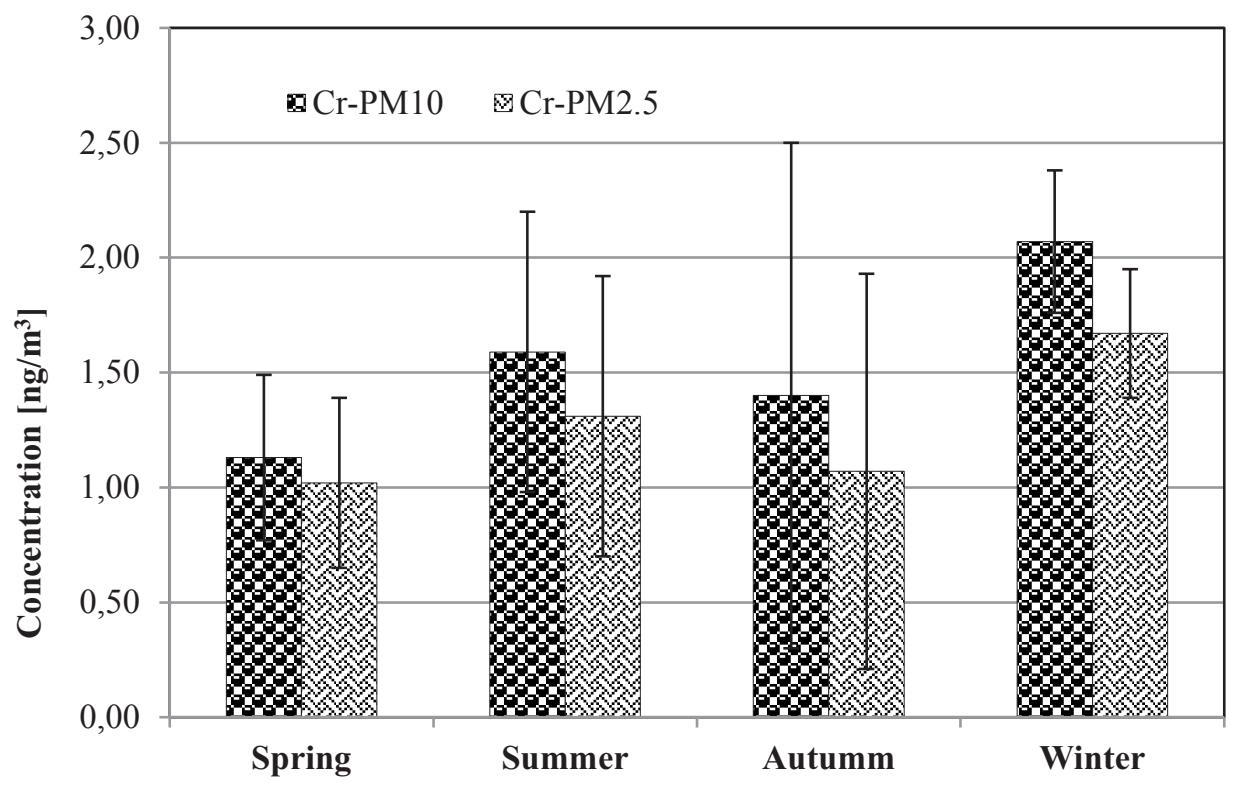

Fig. 3. Concentration of chromium in PM2.5 and PM10 fractions.

The concentration of chromium in PM2.5 varied in the narrow range of 0.38 to 3.2 $\mathrm{ng} / \mathrm{m}^{3}$ (Table 1). Its highest concentration occurred in winter and the lowest in spring. In the case of chromium present in PM2.5 it is also possible to observe the effect of seasonality on its average concentration: winter $-1.67 \mathrm{ng} / \mathrm{m}^{3}>$ summer $-1.32 \mathrm{ng} / \mathrm{m}^{3}>$ autumn -1.07 $\mathrm{ng} / \mathrm{m}^{3}>$ spring $-1.02 \mathrm{ng} / \mathrm{m}^{3}$. It is, however, worth noting that statistically important differences refer only to mean chromium concentrations in the winter-spring period. The characteristic feature of the presence of chromium in the urban air in Radom is also a dominant share of the respirable fraction $(76 \%$ - 90\%) (Fig. 4). This is a very unfavourable situation for Radom inhabitants, as it increases health risk connected with inhalation hazard.

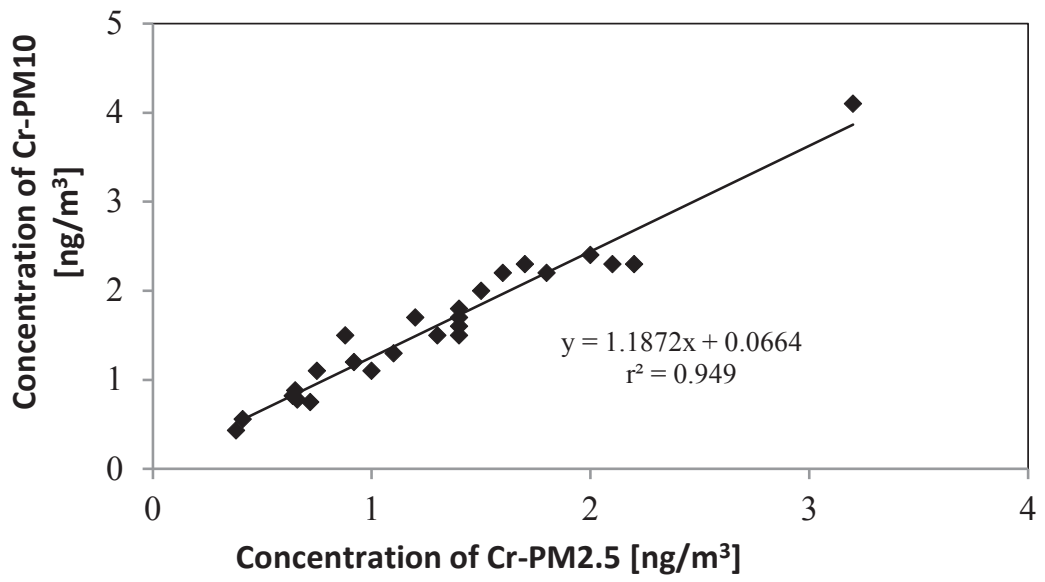

Fig. 4. Interdependence of concentrations of Cr-PM2.5 and Cr-PM10 fractions in urban air in Radom in a one-year period. 
The concentrations of chromium in PM10 and PM2.5 are comparable to those quoted by other authors for urban areas [19-22, 24].

The obtained results of PM2.5 and PM10 concentrations confirm the opinion of Regional Inspectorate for Environmental Protection that the combustion processes in the communal and living sector are the main source of PM in Radom.

It is probable that the observed increase in the concentration of chromium in the winter period results from the same cause. However, without additional analyses, it is difficult to unequivocally conclude whether the main source is combustion in heating plants or burning of fuels in household stoves. The fact that the numbers of samples collected in each of the seasons varied does not facilitate drawing unequivocal conclusions.

\section{Conclusion}

- The results obtained confirmed seasonal changes in chromium concentration in Radom urban air.

- The highest values of chromium concentrations were observed in aerosol samples collected in winter.

- Chromium occurring in PM2.5 equals 76\% to 90\% of chromium present in PM10.

We gratefully acknowledge the financial support from the National Science Center (Poland) grant No. 2011/01/B/ST10/06757, which allowed us to carry out this study.

\section{References}

1. M. Malandrino, M. Casazza, O. Abollino, C. Minero, V. Maurino, Chemosphere 147, (2016)

2. C. Samara, D. Voutsa, Chemosphere 59, (2005)

3. S. M. Tagliani, M. Carnevale, G. Armiento, M. R. Montereali, E. Nardi, M. Inglessis, F. Sacco, S. Palleschi, B. Rossi, L. Silvestroni, A. Gianfagna, Atmos. Environ., 153, (2017)

4. D. Jandacka, D. Durcanska, M. Bujdos, Transport. Res. D-Tr. E., 50, 397-408, (2017)

5. M. J. Gatari, J. Boman, A. Wagner, S. Janhäll, J. Isakson, Sci. Total Environ., 368, 675$685(2006)$

6. Ch. Hsu, H. Chiang, S. Lin, M. Chen, T. Lin, Y. Chen, Sci. Total Environ., 541, (2016)

7. S.M. Talebi, Environ. Res., 92, (2003)

8. Ch. Seigneur, E. Constantinou, Environ. Sci. Technol., 29, (1995)

9. B. Dębski, A. Olecka, K. Bebkiewicz, Z. Chłopek, I. Kargulewicz, K. Kubica, J. Rutkowski, D. Zasina, M. Zimakowska - Laskowska, M. Żaczek, Krajowy bilans emisji $\mathrm{SO}_{2}, \mathrm{NO}_{X}, \mathrm{CO}, \mathrm{NH}_{3}, \mathrm{NMLZO}$, pyłów, metali ciężkich i TZO za lata $2014-2015$ w układzie klasyfikacji SNAP (Warszawa, 2017)

10. K.L. Mandiwana, N. Panichev, T. Resane, J. Hazard. Mater., B136, 379-382 (2006)

11.F. Zhang, Z. Wang, H. Cheng, X. Lv, W. Gong, X. Wang, G. Zhang, Sci. Total Environ., 518-519, (2015)

12. D. Cesari, G. E. De Benedetto, P. Bonasoni, M. Busetto, A. Dinoi, E. Merico, D. Chirizzi, P. Cristofanelli, A. Donateo, F. M. Grasso, A. Marinoni, A. Pennetta, D. Contini, Sci. Total Environ., 612, (2018)

13. M. Arhami, V. Hosseini, M. Z. Shahne, M. Bigdeli, A. Lai, J. J. Schauer, Atmos. Environ., 153, (2017)

14. B. Ambade, Urban Climate, 9, (2014) 
15. K. Zhang, F. Chai, Z. Zheng, Q. Yang, J. Li, J. Wang, Y. Zhang, J. Environ. Sci-China., 26, (2014)

16. A. Saffari, N. Daher, M. M. Shafer, J. J. Schauer, C. Sioutas, Environ. Pollut., 181, (2013)

17. J. Gao, H. Tian, K. Cheng, L. Lu, Y. Wang, Y. Wu, Ch. Zhu, K. Liu, J. Yhou, X. Liu, J. Chen, J. Hao, Atmos. Environ., 99, (2014)

18. S. Y. Jiang, D. S. Kaul, F. Yang, L. Sun, Z. Ning, Sci. Total Environ., 533, (2015)

19. W. Rogula-Kozłowska, B. Kozielska, K. Klejnowski, S. Szopa, Arch. Environ. Prot., 39, (2013)

20. L. Samek, A. Gdowik, J. Ogarek, L. Furman, Environment Protection Engineering, 42, (2016)

21. K. Slezakova, M. C. Pereira, M. A. Reis, M. C. Alvim-Ferraz, J. Atmos. Chem., 58, (2007)

22. L. Samek, L. Furman, M. Mikrut, A. Regiel-Futyra, W. Macyk, G. Stochel, R. van Eldik, Chemosphere 187, (2007)

23. J. S. Pastuszka, W. Rogula-Kozłowska, E. Zajusz-Zubek, Environ. Monit. Assess., 168, (2010)

24. H. Puxbaum, B. Gomiscek, M. Kalina, H. Bauer, A. Salam, S. Stopper, O. Preining, H. Hauck, Atmos. Environ., 38, (2004) 